\title{
Sister Mary Joseph nodule
}

\author{
Stephanie Menzies, ${ }^{1}$ Sanjay Haresh Chotirmall, ${ }_{1}^{1}$ Graham Wilson, ${ }^{2}$ Deidre O'Riordan ${ }^{1}$
}

${ }^{1}$ Department of Internal Medicine, St James Hospital, Dublin, Ireland

${ }^{2}$ Department of Radiology, St James's Hospital, Dublin, Ireland

\section{Correspondence to} Dr Sanjay Haresh Chotirmall, schotirmall@rcsi.ie

Accepted 18 December 2014

\section{DESCRIPTION}

A 72-year-old woman was referred to our emergency department with general malaise and an elevated international normalised ratio (INR) at 15 . Of note, she was on Warfarin therapy for atrial fibrillation. She appeared cachectic and frail. On examination, her abdomen showed no visible umbilical lesion, however a subcutaneous nodule was palpable in the superior aspect of the umbilicus. This raised the suspicion of malignant metastases in view of her weight loss and abnormal INR. CT of the thorax, abdomen and pelvis illustrated a pancreatic mass with liver metastases, ascites and a Sister Mary Joseph nodule (figures 1 and 2). Histology confirmed metastatic pancreatic adenocarcinoma. She was palliatively managed and passed away less than 4 weeks following the admission.

The 'Sister Mary Joseph' sign is an umbilical nodule consequent to metastatic spread from an intra-abdominal or gynaecological malignancy. ${ }^{1}$ Baluff first described umbilical metastases in 1854 . However, Sister Mary Joseph, surgical assistant to William J Mayo, noted the association between an intra-abdominal malignancy and an umbilical nodule back in 1928. Interestingly, William J Mayo was the son of the founder of the well-known Mayo Clinic, where Sister Joseph spent many decades working in the field of nursing. ${ }^{2} 3$ Mechanisms of spread to the umbilicus remain poorly understood but have been postulated as direct haematogenous or transperitoneal spread through lymphatics or alternatively through remnant embryological structures. ${ }^{1}$ While associated with poor prognosis as a presenting sign, it implies advanced metastatic disease as illustrated by our case. ${ }^{1}$

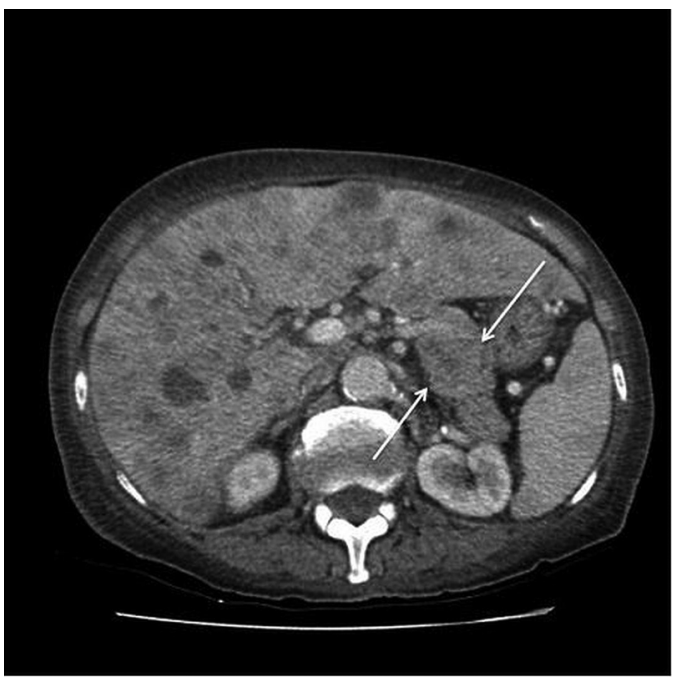

Figure 1 Mass in the tail of the pancreas.

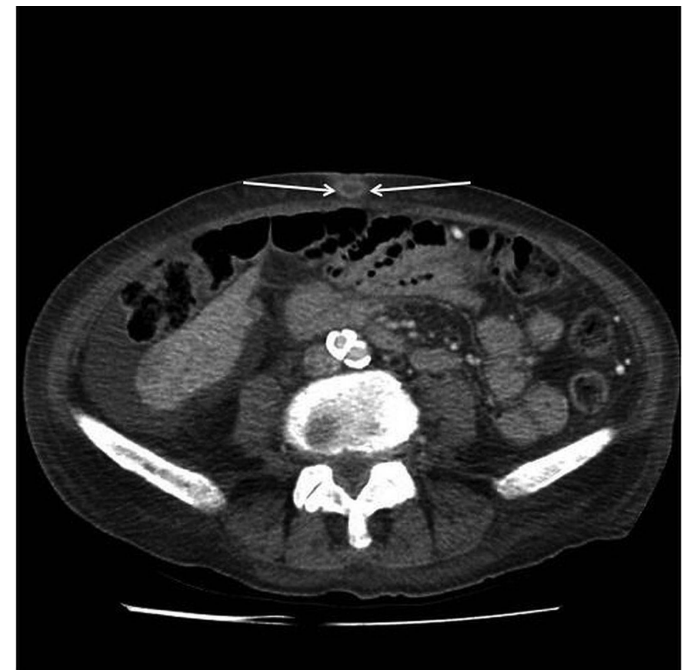

Figure 2 Sister Mary Joseph nodule.

\section{Learning points}

- 'Sister Mary Joseph' sign is an important clinical sign often taught but rarely seen in day-to-day practice.

- It may be associated with intra-abdominal or gynaecological malignancies.

- It indicates a poor prognosis however provides an alternative site of biopsy to confirm a diagnosis.

- The common differential diagnosis of a lump at the umbilicus includes benign causes such as an epidermoid cyst, foreign body granuloma, abscess, urachal remnants and irreducible umbilical hernia in addition to primary malignancy such as a mesenchymal tumour or secondary metastases from an intra-abdominal malignancy.

Contributors SM, SHC, GW and DOR drafted and wrote the manuscript.

Competing interests None.

Patient consent Obtained.

Provenance and peer review Not commissioned; externally peer reviewed.

\section{REFERENCES}

1 Dar IH, Kamili MA, Dar SH. Sister Mary Joseph nodule-a case report with review of the literature. J Res Med Sci 2009;14:385-7.

2 Trebing D, Goring HD, The umbilical metastasis. Sister Mary Joseph and her time. Hautarzt 2004;55:186-9.

3 Akhtar K, Zaheer S, Ahmad S, et al. Sister Mary Joseph's nodule: a rare cytologic presentation. Clin Pract 2011;1:e6. 
Copyright 2015 BMJ Publishing Group. All rights reserved. For permission to reuse any of this content visit http://group.bmj.com/group/rights-licensing/permissions.

BMJ Case Report Fellows may re-use this article for personal use and teaching without any further permission.

Become a Fellow of BMJ Case Reports today and you can:

- Submit as many cases as you like

- Enjoy fast sympathetic peer review and rapid publication of accepted articles

- Access all the published articles

- Re-use any of the published material for personal use and teaching without further permission

For information on Institutional Fellowships contact consortiasales@bmjgroup.com

Visit casereports.bmj.com for more articles like this and to become a Fellow 